\title{
Mellár Tamás: Szemben az árral Rendhagyó közgazdasági előadások
}

\author{
Akadémiai Kiadó, Budapest, 2015, 331 o.
}

Mellár Tamás legújabb könyvének tartalma lényegesen több annál, mint amennyit címe sugall. Bemutatja a neoklasszikus közgazdaságtan - ő ezt a kifejezést nem használja ugyan, de én használni merem - csődjét és az ebből való kiemelkedés összes fontosabb kísérletét. Amint azt a szerző az előszóban leírja, olyan hallgatóknak kellett elöadást tartania, akiknek a túlnyomó többsége már tanult alapszinten mikroés makroökonómiát. Mivel saját igényének valóban megfelelö tankönyvet nem talált (mert ilyen nincs is), az a „mentöötlete” támadt, hogy „rendhagyó” közgazdasági elöadásokat tart, „kritikai megjegyzésekkel és kiegészítésekkel” (5. o.). Amikor ezt a döntését meghozta, feltehetően még nem látta, hogy milyen messze vezetnek majd kritikai megjegyzései és kiegészítései, nála keményebben fogalmazva, egészen a domináns neoklasszikus iskola, a mainstream szinte teljes elutasításáig, a zsákutca felismeréséig és a teljes újragondolás szükségességének bemutatásáig.

A Bevezetés tökéletesen foglalja össze a helyzetet és a szerző álláspontját. Szerinte „a mainstream közgazdaságtan súlyos válságban van, de még nem érkezett el az ideje annak, hogy ez az uralkodó paradigma összeomoljon” (12. o.). „Két irányzat feszül egymásnak, a piacpárti irányzatok ... [szerinte a piaci rendszer] a lehetséges legnagyobb közjót hozzák el a társadalom számára”, míg „a másik irányzat szerint ... szükség van az állam gazdasági szerepvállalására, a piaci müködés korrekciójára." (13. o.) Határozottan kimondja a legfontosabbat: „A korlátok nélküli piaci működés elsődleges haszonélvezői a társadalom töredékét jelentik, csupán a leggazdagabb néhány százalékot. Viszont ezek a csoportok igen erős befolyást tudnak gyakorolni a politikai rendszerre, az oktatásra és a médiára. ... Oda tud[nak] hatni, hogy többségében olyan emberek legyenek közszereplők, tudományos kutatók, tanárok, akik ezt az elméletet képviselik.” (14-15. o.) „A súlyos válság ellenére az is elképzelhető, hogy egyáltalán nem kerül sor paradigmaváltásra, csak némi elméleti korrekcióra, amely esetleg egy-két évtizedre átmeneti megoldást adhat." (12. o.) Saját helyét és álláspontját pedig úgy jellemzi, hogy „az akadémiai közgazdaságtan oldaláról nézve ellenzékinek számít, ... de ádáz küzdelemről szó sincs. ... Szó sincs tehát harcról, legfeljebb arról, hogy a mainstream elmélet tekintélyes képviselőinek képzeletbeli bajszát próbálja egy kicsit megráncigálni.” (15. o.) 
Az 1. fejezet a módszertani alapokkal és a fogalmi lehatárolással foglalkozik. Kiemeli, hogy „egy elméletből több modell is levezethető ... egy sor adatbázis között választhatunk a teszteléshez" (21. o.). Ennek következménye lett a módszertani és elméleti sokszínűség, és ezért „nincsenek sziklaszilárd alapjaink az egyes elméletek elbírálása során” (23. o.). Ezzel, még ha amit leír, valós is, és ad is teszteket a követett eljárás helyességének megítélésére, a szerző veszélyes útra lép, mert ez a gondolkozás arra az eredményre vezethet, hogy nincs mód a következtetések helyességének megítélésére. Az ezt követő nagyon fontos részben a mainstream és a nem mainstream irányzatok megkülönböztető jegyeit sorolja fel. E felsorolásból itt csak azt emelem ki, hogy a mainstream gondolkozás szerint „a közgazdaságtan értékmentes”, a nem mainstraim gondolkozás szerint „nem értékmentes”, „következtetéseit jelentős mértékben befolyásolja az ideológia” (29. o.), és nagyon határozottan foglal állást a nem mainstraim gondolkozás mellett. Az itt leírtak szorosan összefüggenek a Bevezetésnek azzal a megállapításával, hogy a közgazdaságtudományi állásfoglalásokat az érdekviszonyok is befolyásolják.

A 2. fejezet a gazdaság, a társadalom és a környezet kapcsolatát tárgyalja, és több szempontból is nagymértékben túllép a hagyományos elemzés valamennyi ágán. Kiemeli ugyanis a gazdaság, a társadalom és a környezet közötti szoros kapcsolatot, ami radikális szakítás a mainstream gondolkozással, ahol nem - vagy csak mintegy a függelékben jelennek meg a társadalmi és környezeti szempontok. E szempontoknak a gazdasági gondolkozásba való integrálása elkerülhetetlen, mert megengedhetetlen, hogy a gazdaság maga alá gyürje a társadalmat és a környezetet, mint ahogy ez a modern kapitalizmus és a globalizáció világában, a szemünk előtt megy végbe.

Az itt leírtakból ki kell emelnem három nagyon fontos konkrétumot. Az egyik Magyarország térvesztése a többi kelet-közép-európai országhoz képest az ezredforduló után. Erre nem tud magyarázatot adni sem a főirány, sem a szerző, és a magyarázatot szerintem még csak nem is a gazdasági, hanem a történelmi, társadalmi és politikai tényezőkben kereshetjük. A másik az a Stiglitztől idézett tétel, hogy „a jólét leszivárgásának tana ... sosem volt több puszta hittételnél” (42. o.), és ezért fontos gazdaságpolitikai célnak kell tekinteni a jövedelemelosztás etikai követelményeknek megfelelö alakulását, mert e nélkül lehetetlenné válik nemcsak a társadalom fölemelkedése, hanem a gazdasági növekedés is. A harmadik, hogy a gazdasági hatalom maga alá tudja gyürni a politikai hatalmat is.

A fejezet ezt követő része a népesedés és a környezet problémáit tárgyalja. A népesedés tárgyalását leegyszerüsített módon, a környezeti problémák leglényesebb elemeit igen jól mutatja be a szerző. Definiálja a környezeti szempontok szerinti fenntarthatóság fogalmát, foglalkozik a növekedés határaival, és nagy teret szentel a globális felmelegedéssel foglalkozó Stern-jelentésnek. Mindezzel messze túllép a közgazdasági elemzésnek a fóáram által meghatározott keretein, amit nem lehet eléggé helyeselni.

A 2. fejezetben leírtak logikus folyománya a 3. fejezet, amelynek címe A gazdaság neoklasszikus értelmezése. A szerző Samuelsonnak azzal a tételével indít, hogy „nincs külön közgazdasági elmélet a republikánusok, a demokraták, a munkások, a munkaadók, az oroszok számára, és ismét más a kínaiak számára”, és arra jut, hogy „elég jelentősen elválik egymástól a fejlett és a fejlődő országok közgazdaságtana" (55. o.). Samuelsonnak ez a tétele valóban vitatható, mert ellentétes a 
tapasztalatokkal, hiszen mi sem nyilvánvalóbb, mint hogy az eltérő elveket és így szükségképpen eltérő elméleti hátteret alkalmazó nemzeti gazdaságpolitikák nagymértékben különböző eredményekre vezetnek; elég itt a mainstreamtől eltérő elveket követő ázsiai országok gazdasági sikereire utalni. Szörnyü következményekkel járt az állítólag a világ egészére egyformán érvényes elvek alkalmazásának erőltetése és az országok speciális körülményeinek el nem ismerése: számos fejlődő ország felzárkózásának megtörésével és - ami számunkra a legfontosabb - a volt szocialista országok transzformációs válságának kimélyülésével, majd lassú felzárkózásával, amire a tudomány világának egyetlen tagja sem számított, és aminek fő oka az állítólag a világ egészére egyformán érvényes elvek alkalmazásának erőltetése és ezen országok speciális körülményeinek el nem ismerése. Végül, sajnálatos módon vitatnom kell a szerzőnek azt a megállapítását, hogy „elég jelentősen elválik egymástól a fejlett és a fejlődő országok közgazdaságtana”. Ennek így kellene lennie, de a mainstream elhomályosította a valaha önálló tudományágnak számító és Nobeldíjakkal is jutalmazott fejlődés-gazdaságtant.

E fejezet összefoglaló kiinduló tételének az tekinthető, hogy „a gazdasági problémák tudományos igényű vizsgálatához a szűkösség és a racionalitás feltételezése sem nem szükséges, sem nem elégséges" (56. o.). Ennek megfelelően e fejezet két részre, a szűkösség és a racionalitás kérdésének tárgyalására válik szét.

A szükösség mainstream szerinti centrális szerepét a szerző azzal cáfolja, hogy „a társadalmilag alakuló célok és szokások, valamint a rendelkezésre álló technikák, technológiák együttesen alakítják az értékelést, és így radikálisan meg tudják változtatni a készleteken alapuló szűkösségi viszonyokat” (59. o.). Az viszont kétségtelen, hogy a környezet egésze szűkös tényezö, és ezért „a közösség tagjai olyan és annyi gazdasági aktivitást alkalmaz[hat]nak, amennyi nem veszélyezteti a föld regenerációját" (61. o.). E rész foglalkozik még a Ramsey-modellel, a kamat kérdésével, sőt Silvio Gesellel és a nyugdíjrendszerrel is, e kérdések e keretek közi tárgyalása azonban csak nagyon rövidre fogott és ezért némiképp felületes lehet.

A racionalitás kérdésének nagyobb figyelmet szentel a szerző. Mondanivalójának lényegét abban látom, hogy „a racionális viselkedés csak egy alapfeltevés”, amelynek „alkalmazásával sokkal egyszerűbb, áttekinthetőbb és matematikailag jól kezelhető struktúrákat kapunk. ... A viselkedési közgazdaságtan kísérletei azonban határozottan ellentmondanak ennek a racionalitási feltételezésnek" (67. o.) - ugyan melyikünk állíthatja, hogy viselkedése teljesen racionális. A racionális várakozások tárgyalása során a szerző le is írja, hogy „nyilvánvaló”, „hogy a vonatkozó mainstream érvelés mennyire tautologikus” (73. o.). A racionalitás feltételezése tehát - éppúgy, mint a tökéletes és ingyenes informáltság feltételezése stb. - operatív szükségszerűség a föirány hívei számára.

A mikroszint és a makroszint összekapcsolása (4. fejezet) jellegében kissé eltér az eddig tárgyaltaktól: nem megy szemben a föárammal. A mikro- és a makroszint összekapcsolásának újabb kísérlete a keynesi szellemủ makroökonómiát utasítja el azzal, hogy kikényszeríti a makroökonómia mikroökonómiai megalapozását, vagyis a keynesi alapokról a mainstreamnek megfelelő neoklasszikus alapokra helyezését. Vitatható a szerzőnek az a tétele, hogy „miközben egyre többet tudunk az egyes gazdasági szereplök viselkedéséről, a gazdaság egészének müködése továbbra is rejtély" (78. o.). 
A gazdaság egészének müködése szerintem csak azért rejtély sokak számára, mert elutasítják Keynes tanításait, amelyekhez pedig vissza kellene térnünk.

E fejezet további részei először azt tárgyalják, hogy a robinsoni gazdaságnak nincs relevanciája a valódi gazdaságokra (80. o.), majd azt, hogy az egyéni keresleti függvények ágazati keresleti függvényekké való integrálása és így a makroökonómia mikroökonómiai megalapozása távolról sem problémamentes. A továbbiak bemutatják a makrogazdasági körfolyamatok sematikus ábráját és azt, hogy a „,kétszereplős zárt modell helyett az állammal kibővített, háromszereplős nyitott modellt” kell használnunk, „bevezet[ve] a pénz- és tőkepiacot is" (89. o.). Ezt az aggregálás, az indexálás, az Egyesült Államokban erre alkalmazott eljárás helyességét vizsgáló Boskin-jelentés és a GDP mint mutató relevanciájával és a Stiglitz-bizottság ezzel kapcsolatos megállapításaival foglalkozó részek követik, de ezek a részek nem, vagy csak alig lépnek túl a hagyományos elemzés keretein. Ugyanez a megállapítás vonatkozik a mezoszinttel és a szerkezeti problémák kezelésével foglalkozó függelékre is, amely Quesnay gazdasági tábláitól Marx újratermelési sémáin és Neumann autópálya- (turnpike-) modelljén keresztül az ágazati kapcsolatok mérlegéig (ÁKM) és a társadalmi elszámolási mátrixig (SAM) jut el.

Az 5. fejezet a csökkenő hozadék kérdésével foglalkozik. Káldornak azzal a gondolatával indít, hogy „hacsak nem feltételezhetjük, hogy az egyensúlyi ponton a marginális költségek a kibocsátással általában növekednek, ... az alap, amelyre a gazdasági törvények építhetők, megrendül” (109. o.). Ugyanez egyszerübben kifejezve: a mainstream szerint a termelés felső határa ott van, ahol a marginális költségek növekedése miatt már nem érdemes kiterjeszteni a termelést. Ha viszont a marginális költségek nem nőnek, akkor a termelésnek nincs a költségoldalról meghatározott felső határa, és a hagyományos elmélet tarthatatlanná válik.

Az ezt követő részben a szerző a hagyományos elméletet tekinti át. Foglalkozik a Cobb-Douglas-féle termelési függvénnyel és a belöle eredő következtetésekkel, az ezen alapuló neoklasszikus jövedelemelosztási elmélettel, és félreérthetetlenül bizonyítja, hogy a neoklasszikus elmélet nem magyarázza meg a valóságban tapasztalható jövedelemkülönbségeket. Érvelését ki kell egészítenem olyasmivel, amire ő nem hivatkozik. Míg a japán menedzserek bére nyolc japán munkásénak felel meg, ez az arány az Egyesült Âllamokban már 100-as nagyságrendü. Semmi sem bizonyítja, sőt teljesen valószerütlen, hogy az amerikai menedzserek hatékonysága több mint tízszerese a japánokéinak.

A szerző által bemutatott reális megoldás a reális tényekből indul ki. Az üzemek mindenütt kapacitásfelesleggel müködnek, hogy alkalmazkodni tudjanak a kereslet növekedéséhez, ami mindig előadódhat. Ez azt jelenti, hogy a termelés növelése nem jár költségnövekedéssel, sőt - amit a szerző nem ír le - valószínüleg inkább költségcsökkenést eredményez, mert növekvő termelés esetén a termékegységre jutó fix költség csökken. Emellett „az iparban működő vállalatok általában ármegállapítók”, és nem árelfogadók, ahogy ezt a hagyományos elmélet feltételezi, „és a hosszú távú túlélésre és expanzióra törekszenek a rövid távú profitmaximalizálás helyett" (127. o.), ismét a hagyományos elmélet feltételezéseivel ellentétben. Mindezek következtében Sraffa 1926-os (Keynes előtti) keynesiánus válasza szerint „a kereslet nagysága” „határozza meg a kívánatos termelés szintjét" (125. o.). Ismét kiegészítve a szerző érvelését, ez tökéletesen megfelel az 
összehasonlító közgazdaságtan azon alaptételének is, hogy a termelés a kapitalizmusban keresletkorlátos, míg a szocializmusban kapacitáskorlátos volt. A leírtakból egyenesen adódik az a kiáltóan keynesi következtetés is, hogy a munka keresletét a termelés menynyisége iránti igény határozza meg, a legélesebb ellentétben a neoklasszikus feltételezésekkel, és ezzel ott vagyunk a keynesi kényszerü munkanélküliségnél.

A szerző a 6. fejezetet az eddigiek logikus folyományaként az általános piaci egyensúly és egyensúlytalanság kérdésének szenteli. Már a fejezet legelején megadja a fejezet helyét a könyv egészében. „Az első részben megmutatjuk, hogy a mainstream felfogás hallgatólagosan igen sok alapfeltevéssel él, ... továbbá arra is rámutatunk, hogy a még olyannyira szigorú alapfeltevések mellett is kétséges a piaci egyensúly és az egyensúlyi konvergencia léte." (133. o.)

Először az előbb leírtakkal összhangban a piaci mechanizmus hagyományos ábrázolásának, a Marshall-keresztnek a többnyire hallgatólagos alapfeltevéseit mutatja be. Érdemes ezeket itt is felsorolni: a termékek homogének; a kereslet és a kínálat csak a piaci ártól függ, a többi befolyásoló tényező exogén módon rögzített; az egyes szereplők keresleti szándéka független egymástól és a kínálattól is; az egyes kínálati szándékok is függetlenek egymástól és a kereslettől is; az egyes szereplők nem tudják számottevő mértékben befolyásolni az összes kereslet és összes kínálat nagyságát. Könnyü belátni, hogy ezek a hallgatólagos alapfeltevések nem felelnek meg a valós tényeknek.

Ezután a szerző a piaci mechanizmus ma már tankönyvi szintünek tekinthető problémáival foglalkozik. Először a pókhálótétellel, majd a buborékok kialakulásával és konkrétan „a 2008-ban kirobbant válság kapcsán elhíresült ... amerikai ingatlanbuborék[kal] és kirobbanásá[val]" (142. o.), majd nagy teret szentel Bródy András piaci alkalmazkodási modelljének. Az igazán új azonban Akerlof modellje a használt autók piacának sajátos működéséről, valamint a munkapiac és a hatékony bérek Shapiro és Stiglitz által kidolgozott elmélete, amelynek folytán „szükségképpen jelenik meg a kényszerü munkanélküliség” (151. o.). Kár, hogy a szerző nem foglalkozik Spence-szel, mert ők hárman alakították ki - egyes esetekben másokkal is együttmüködve - az aszimmetrikus információk piaci hatásának elméletét, és kaptak ezért, hármuk között megosztva, Nobel-díjat.

E fejezet lezárásaként a szerző összefoglalja a valóságos piac működésének hat alapvető tulajdonságát, és érdemes ezeket is felsorolni: 1 . nincs egyetlen egyensúlyi ár; 2. a piacok sohasem tisztulnak meg; 3. a kapacitásnak és a készletszintnek nagy a fontossága; 4 . a kereslet és a kínálat nem koncentráltan jelentkezik; 5 . a kereslet és a kínálat nem független egymástól; 6 . a piaci müködés nem statikus, hanem dinamikus. E hat tétel egyértelmüen és világosan mutatja, hogy milyen mértékben valóságidegen a piacok működésének mainstream elmélete, és e tételeknek az e fejezet bevezetésében felsorolt tételekkel való összehasonlítása nagyon jól rávilágít a mainstream és a korszerű elmélet közti eltérésekre.

A 7. fejezet a piaci rendszer és az általános egyensúlyi elmélet kapcsolatát elemzi. Először ismerteti a klasszikus-neoklasszikus piacfelfogás kialakulását Smithtől Walrason át az Arrow-Debreu-szerzőpárosig és Hayekig, valamint a racionális várakozások elméletéig. Ezt követi a marxista piacfelfogás bemutatása és kritikája, amelynek végső megállapítása, hogy a szocializmus „a kapitalizmusnál mindenképpen 
alacsonyabb rendű, mert nem hatékony gazdaságot eredményez" (164. o.). Ezt az általános egyensúlyelmélet problémáinak még mindig a konvencionálison nem sokban túllépő elemzése követi, Walras modellje, valamint a Wald Ábrahám és Neumann János által megfogalmazott bizonyítás a megoldás létezésére, majd ezután az érvelés visszatér Arrow-ra és Debreu-re. Az ismertetés a Say-törvénnyel, valamint Clower és Leijonhufvud ezzel kapcsolatos fejtegetéseivel végződik.

A fejezet és talán a könyv csúcsa ez után következik, A piacgazdasági modell és a valóság ütköztetése című alfejezetben. Itt a szerző azt írja le, hogyan szivárognak be „a társadalmi hatások” „a piaci rendszerbe” (179. o.), hangsúlyozva a gazdasági, társadalmi és környezeti elemek teljes egységét és elválaszthatatlanságát. Azzal a mainstream felfogással ellentétben tehát, amely e három rendszer elkülönítésére törekszik, a leghatározottabban hangsúlyozza e három szerves és szükségszerü egységét, és annak káros hatását, ha az egyik - a modern piacgazdaságban a gazdasági - túlsúlyra jut. Nem kevésbé káros lehet azonban az is, ha „a viselkedési módok, attitüdök, társadalomszervezési módok nem változnak" (182. o.), és a szerző szerint „a magyar gazdaság elmúlt száz évének teljesítménye, müködésének módja, makrojellemzői ... szinte ugyanazok ... maradtak ... a legutóbbi száz évben” (181. o.), vagyis távolról sem kielégítő gazdasági teljesítményünknek elsősorban társadalmi és politikai okai vannak. E következtetés fontosságát és igazságát is alig lehet eléggé hangsúlyozni, azzal együtt, hogy társadalmi rendszerünk és intézményeink „valójában nem biztosítják a szó eredeti értelmében a nép uralmát" (uo.).

A 8. fejezet a véletlen szerepét tárgyalja a pénzügyi piacokon, és az előzővel ellentétben inkább leíró jellegü. Először a hagyományos felfogást tárgyalja, amely „éles különbséget tesz a befektető és a spekuláns között” (183. o.), majd visszatér a hatékony piacok mainstream elméletére, és Eugen Fama érvelését követve ismerteti az ilyen piacok létrejöttének feltételeit. Telebet idézve a következőket írja az 1998-ban csődbe jutott Long Term Capital Management (LTCM) nevü fedezeti alapról: „Ez a cég két zseninek mondott Nobel-díjas közgazdászt foglalkoztatott, az ő kockázatkezelési módszereiket alkalmazta, amelyekről utóbb kiderült, nem mások, mint bugyuta, haranggörbeszerű matematikai levezetések. Mégis meggyőzték saját magukat arról, hogy amit művelnek, az magas szintủ tudomány, s akkora volt a hatásuk, hogy sikerült az egész pénzügyi világot a feje tetejére állítaniuk. A történelem egyik legnagyobb mértékü üzleti vesztesége minden előjel nélkül, szinte egy szempillantás alatt következett be.” (193. o.) Éppen ezért állíthatjuk, hogy Merton és Scholes Nobel-díjjal való jutalmazása a díj történetének legsúlyosabb tévedése. A fejezet második része a véletlen újraértelmezésével foglalkozik, Keynest idézve, aki szerint „a bizonytalanság olyan helyzetekre alkalmazható, ahol nincs tudományos alap, amelyre támaszkodva számítható valószínűség formájában volna" (194. o.). Kár, hogy a szerző nem foglalkozik a Nobel-dijas Douglass North elméletével, amelynek középpontjában a számítható valószínűség és a kiszámíthatatlan bizonytalanság megkülönböztetése áll. A szerzö a 198. oldalon összehasonlítja a tözsdeindex és a véletlen Brown-mozgás varianciáját. Arra a következtetésre jut, hogy „,az árváltozások nem követnek normális eloszlást ... Következésképpen azok a pénzügyi modellek, amelyek a »jól viselkedö", a Gauss-görbe által leírható véletlen hatást tételezik fel, szükségképpen rosszul becsülik meg a befektetések reális kockázatát." (201. o.) 
A konjunktúraciklusok és gazdasági válságok kérdésével foglalkozó 9. fejezetnek már az első mondata megállapítja, hogy „a gazdasági válságokról szóló fejezetek általában hiányoznak a mainstream tankönyvekböl, ... vagy ha mégis megjelennek, akkor olyan tálalásban, mint a nagy természeti csapások, földrengések" (207. o.), ami azzal az állítással egyenértékü, hogy ezeknek nincs is mainstream elméletük. Ez az állítás még csak nem is megalapozatlan, mert ha a mainstream ,jól viselkedő”, ,„egyensúlyi” körülmények feltételezéséből indul ki, akkor ebben az elméleti képben nincs helyük a válságoknak.

A válság- és cikluselméleteket a szerző Marxtól Keynesen át Kondratyevig mutatja be, és ez az elemzés is Keynes aktualitását bizonyítja. A fejezet utolsó része a 2008. évi válságot elemzi. A szerző szerint „hangsúlyozottan ki kell emelni az inflációs célkitüzésű monetáris politika elégtelenségét” (228. o.), továbbá, hogy Krugman szerint „a nagy világválságban a vezetőknek volt mentségük: igazában senki sem tudta, hogy mi történik, és hogyan lehetne kezelni a válságot. A mai vezetőknek azonban nincs mentségük, mert tudjuk, hogy mi történik, és rendelkezésükre állnak az eszközök is, amelyekkel véget vethetnénk ennek a gyötrelemnek." (229. o.)

A neoklasszikus szintézis vagy a keynesi közgazdaságtan vége címü 10 . fejezet az elképzelhető legjobban fejezi ki a lényeget. Az IS-LM, valamint az $A D-A S$ elemzés, amelyeken felnevelkedtünk, amelyek ma is dominálják a tankönyveket, és amelyeket úgy adtak el nekünk, mint Keynes gondolatainak tökéletes, bár a tankönyvek számára kissé leegyszerüsített formáját, valójában a keynesi közgazdaságtan végét jelentik. Nem jelenthetik azt! Akkor jelenthetnék, ha Keynes gondolatai nem lennének ma is igazak, és nem ők adnák meg a kiutat számunkra ma is.

E fejezet a rövid bevezetést követően a korszerü közgazdasági gondolkozás két kiemelkedő alakját idézi. Leijonhufvud szerint „,a régi neoklasszikus szintézis ... intellektuális csalás volt. Ez a csalás évtizedekre meghiúsította a gazdasági rendszer instabilitásának vizsgálatát”. Taleb szerint „egyrészről Paul Samuelson, másrésztől pedig John Hicks volt az, akik bevezették a »formális elemzés« nevü játékot. ... Ez a két ember tönkrezúzta John Maynard Keynes elméleteit, miközben megpróbálták őket leképezni. ... A neoklasszikus konszenzus eredményeképpen egy olyan, Keynes nevével fémjelzett, de valójában az ő eredeti szándékától igen távol álló ... makroökonómia jött létre, amely ... súlyos kudarcot vallott. A kudarc valójában nem Keynes és a keynesi makroökonómia hibás voltát bizonyította, hanem a hibás alapokra felépített neoklasszikus szintézisét. Az akadémiai közgazdaságtan és a közgazdász-társadalom nagy része mégis úgy értékelte, hogy valójában maga a keynesianizmus bukott meg. Ez a félreértés, félreértelmezés azért válhatott uralkodóvá, mert a közgazdászszakma valójában sohasem értette vagy nem akarta megérteni a keynesi kritika lényegét, és nem akart, vagy nem tudott elszakadni a hagyományos, 19-20. századi neoklasszikus alapoktól.” (239-240. o.)

A könyv ezután igen részletesen, 15 oldalon, Modigliani 1944. évi tanulmányából kiindulva ismerteti az $I S-L M$ és az $A D-A S$ rendszert, majd áttér a szintézismodelleken alapuló gazdaságpolitikai elemzésre. Először a keynesinek mondott nagyméretü modelleket és a Lucas-kritikát tárgyalja. Rámutat, hogy a felmerülő problémákat a racionális várakozásokon alapuló modellekkel próbálták megoldani, és arra a radikális következtetésre jut, hogy „a strukturális modellek Lucas-típusú kritikája nem megalapozott” (257. o.). Nem kevésbé radikális az a következtetése, hogy „miközben 
a mainstream jelentős erőfeszítéseket tesz annak megmagyarázására, hogy a növekvő termelés miként egyeztethetö össze az emelkedő reálbérekkel, csak annyit kellene tennie, hogy elfogadja a konstans vagy növekvő tényezőhozadék tényét és/vagy a hatékony bérek elméletét". (260. o.) Ezekkel a szerző részletesen foglalkozott az 5. és 6. fejezetben. A fejezet utolsó része nem kevésbé radikális, és a munkanélküliség természetes rátájának neoklasszikus értelmezését vonja kétségbe.

A könyv utolsó két fejezete (a 11. fejezet címe: Az újklasszikus makroökonómia és a neoklasszikus szintézis, illetve a 12. fejezet címe: Merre tovább, közgazdaságtan?) áttekintést próbál adni a legújabb, még nagyrészt teljességgel kiforratlan közgazdaság-tudományi irányzatokról. Itt olyan kérdéseket tárgyal, amelyekben a legtöbb olvasó, sőt a recenzens is gyakorlatilag teljesen tájékozatlan. A helyzetet talán a 12. fejezet bevezető mondatai írják le a legjobban. „Az elmúlt évtizedekben felgyülemlett tanulmányok, tankönyvek és empirikus kutatási eredmények elég széles körü megalapozást biztosítanak a föirány jó néhány tételének megkérdőjelezésére. Ebből a tényből azonban nem feltétlenül következik, hogy rövid időn belül paradigmaváltásra számíthatnánk a közgazdaságtanban. Még a 2008-ban kirobbant és máig elhúzódó gazdasági világválság sem rengette meg a közgazdaságtan építményét és teoretikus struktúráját. ... Azt viszont nem lehet tagadni, hogy a válság kitörése után megszaporodtak a kritikai jellegü írások, és egyre több közgazdász kezd kicsit másként gondolkodni a dolgokról, esetenként akár kételkedni is a korábban sziklaszilárdnak hitt elméleti konstrukciókban. ... Az 1929-1933-as nagy válság kitörése után is majd egy évtized telt el, a míg megjelent Keynes forradalmi könyve, és ezt követően újabb tizenöt-húsz évet kellett várni, amíg az akadémiai közgazdaságtan köreiben is polgárjogot nyert a keynesianizmus. Ebből a szempontból tehát nincsen abban semmi rendkívüli, hogy az elmúlt években nem történt paradigmaváltás." (295. o.)

Az itt leírtakat még jobban megerősítik a 11. fejezetnek a magyar gazdaságot példaként érintő megállapításai. „Közismert, hogy a külső egyensúly többnyire akkor valósul meg, ha gazdasági növekedésünk 0 százalék körül vagy inkább az alatt van ..., továbbá az is, hogy „a munkanélküliségi ráta 7 százalék alá csökkentéséhez 4 százalékos növekedési ütemre lenne szükség” (282. o.). Minthogy negatív külső egyensúllyal a tartós gazdasági növekedés és a munkanélküliség csökkentése nyilván lehetetlen, ez azt jelentené, hogy várjunk mintegy csekély 25 évet, amíg a közgazdászszakma fennkölt képviselöi egyetértést alakítanak ki a helyzet megítélését és a teendőket illetően, és addig nézzük végig, ahogy a teljes munkabíró lakosság, a helyzet teljes reménytelenségét nemcsak látva, hanem a bőrén érezve, kivándorol a világ négy tája felé?

A 11. fejezet először bemutatja, hogy az újklasszikus iskola három szigorú alapfeltevéssel él, ami szándékaik szerint markánsan megkülönbözteti őket a keynesi szintéziselmélettől: 1. a makroökonómiai mikromegalapozásának igénye, 2. a rugalmas árak és bérek, és ennek folytán a piactisztítás feltételezése és 3. a racionális várakozások. Mindezek alapján kimondják, hogy a monetáris és a költségvetési politika egyaránt hatástalan, ami az előbb leírtakkal ellentétben voltaképpen azt jelenti, hogy nem csupán mintegy 25 év gondolkozási ideig, hanem a végtelenségig kell tétlenül néznünk az eseményeket. Szakma még nem mondta ki ilyen egyértelmüen a saját értelmetlenségét és feleslegességét! A fejezet ezután röviden bemutatja a mikro- 
megalapozás nehézségeit, a racionális várakozások feltételezésének problémáit, valamint a gazdaságpolitikai előrejelzések sikertelenségeit.

Ezt követi a szerző eléggé radikális ítélete. „Az új neoklasszikus szintézis célja nagyon is régi volt: a keynesi makroökonómia és a klasszikus mikroökonómia összebékítése. Ez első látásra nyilván elég reménytelen vállalkozás, mert a teljes foglalkoztatás melletti makroegyensúlyt nem lehet együtt tárgyalni a keynesi kényszerü munkanélküliséget tartalmazó egyensúllyal.” (283. o.) Kiútként a következőket javasolja: 1. többdimenziós jelleg (a makroegyensúly vizsgálata nem egy kiválasztott értékpár egyezőségének ellenőrzését, hanem egy sokelemü mutatórendszer értékelését jelenti, 289. o.); 2. nem szigorú egyensúly, hanem az egyensúlytalansági állapotok sajátos rendszere (makroszinten sohasem lehet megkövetelni a walrasi általános egyensúly teljesülését, 290. o.); 3. sztochasztikus jelleg (szemben a hagyományos, determinisztikus felfogással a gazdaság mindenkori állapotát valamilyen sztochasztikus folyamatként kell értelmezni, 291. o.); 4. dinamikus jelleg (statikus, komparatív statikus szemléletmód helyett igazi, valóságos dinamikára van szükség, 292. o.).

A szerző felsorolja, hogy a sok-sok szóba jöhető irányzat közül melyeket látja a legfontosabbaknak: 1. intézményi közgazdaságtan, 2. viselkedési közgazdaságtan, 3. ágensalapú modellezés, 4. evolucionista közgazdaságtan, 5. fejlödés-gazdaságtan, 6. posztkeynesi közgazdaságtan, 7. új gazdasági földrajz, 8. új (endogén) növekedési elmélet, 9. ökológiai irányzat, 10. népesedési (populációs) modellek, 11. kaotikus rendszerek vizsgálata (295. o.).

Az Utószó méltó befejezése az itt leírtaknak. Először a következőket idézi: „A newtoni világkép győzelmével úgy látszott, hogy nincs helye a tudományban a választásoknak és az értékeknek. A klasszikus tudomány a stabilitást és az egyensúlyt hangsúlyozta, most viszont instabilitást, fluktuációt és evolúciós trendeket látunk minden tudományszak területén a kozmológiától a kémián át egészen a biológiáig.” (313. o.) Ez után a következőkkel zárja a könyvet: „A jelen és a jövő közgazdász-generációinak, tudósainak mindenekelőtt vissza kellene szerezniük a közgazdaságtan társadalomtudományi státusát, és csak ezt követően kezdhetnének el gondolkozni a megvilágító erő fokozásáról.” (314. o.) E recenzens továbbmegy: a közgazdaság-tudománynak vissza kell szereznie a közgazdaságtan etikai és alkalmazott tudományi státusát, amely a tudomány alapító atyáinak idejében még megvolt. Ha e tudomány nem arra törekszik, hogy megtalálja az utat a méltányos jövedelem- és vagyonelosztáshoz, a teljes foglalkoztatáshoz és a mindenkire kiterjedő közjóléthez, akkor, amint ezt a könyv legutolsó fejezetei félreérthetetlenül mutatják, hatástalanul szétfolyik, mint a homokra öntött víz.

Külön meg kell még emlékeznünk a 17 oldalas, páratlan szorgalommal összeállított irodalomjegyzékről, amely lehetővé teszi az olvasó számára a korunk közgazdaságtudományában való tájékozódást. Reméljük, hogy Mellár Tamás e kötetét tankönyvként használják majd valamennyi egyetemünkön, ami elösegíthetné, hogy a magyar közgazdaság-tudomány kiszabaduljon az idejétmúlt szemlélet béklyóiból. 